multidirectional core interests of the international relations' parties, which lay the firm basis for autonomy seeking, until the eventual secession. The determinants of secessionism support are summed up as follows: the existence of regional political parties; a certain degree of decentralization; ideas about the weakness of the state in which secessionist regions are incorporated. Opinions and conclusions about the economic background of secession or secessionism may be possibly born by an internal conflict or weak administration, or may be formed as regional asymmetries and economic crises aggravate.

Key points in favor of large territorial units can be summed up as follows: large economies lay fertile grounds for the development of powerful industries; large economies can supply the public sector with high skilled officials; large markets can work without administrative or trade borders; the regions can be protected or secured from external shocks; a diversified economy is capable to avoid structural problems. The economic consequences of secession will depend on: the degree of society's fragmentation; institutional constrains, policies making use of or limiting the benefits of globalization.

Keywords: secession, separatism, economic determinant, economic security, economic effect.

УДК 378.1.014.24

Y. I. Chentukov

T. V. Marena

\title{
HIGHER EDUCATION INTERNATIONALIZATION AS A FACTOR OF IMPROVING UNIVERSITY COMPETITIVENESS
}

The paper dwells on estimation of the relationship between internationalization and competitive advantages of higher education institutions on the example of three European universities (University of York, University of Tartu, Vytautas Magnus University), and determining to what extent internationalization impacts university competitiveness. It is stated that the rank and the score of the university in world universities rankings can be considered as the most generalizing and comprehensive indicators of the university competitiveness level. It is found out that most of the world universities rankings take into account indicators that characterize university's international activity. Analysis of the overall score of three European universities and the indicators of their internationalization shows that an increase in internationalization indicators entails an increase in the overall score of the university and its improved positions in the corresponding rankings. Comparing universities' data on international students and international staff demonstrates that these indicators matter for the overall score of the university by QS World University Rankings and consequently for its competitiveness. The comparative analysis of internationalization profile of the universities made it possible to identify the specific constituents of the universities' success in the field of internationalization progress and obtaining competitive advantages.

Key words: higher education internationalization, university competitiveness, universities rankings, international faculty, international students.

DOI 10.34079/2226-2822-2020-10-19-104-112

The terms of tough competition in which universities operate all over the world require, on the one hand, the expansion of educational services markets through the internationalization of educational activities, and on the other hand, finding the ways of enhancing the level of 
universities' competitiveness and improving the quality of higher education. Only competitive university which is able to provide educational services of high quality can survive on global markets, successfully competing with other institutions. At the same time, universities' active participation in the process of internationalization provides good chance for them to obtain new competitive advantages and to improve the quality of education, as far as internationalization is considered to be a means to achieve higher education quality for society.

Theoretical issues and practical problems of development of higher education internationalization processes are sufficiently highlighted in scientific studies provided by $\mathrm{O}$. Bulatova [1], F. Hunter [2; 4], J. Knight [3], R. Nolan [4], H. de Wit [2; 3] and other researchers. These studies dwells on the origins and evolution of internationalization processes in higher education, pros and cons of these processes, their peculiarities in different countries and regions of the world. On the other hand, the scientific studies of O. Bulatova [1], J. Sadlak [8], J. Salmi [7] are devoted to determining the theoretical impact of higher education internationalization on the competitiveness of universities and education system in general.

Alongside it, the relationship between the indicators of higher education internationalization and the level of the university competitiveness requires appropriate quantitative assessments and empirical evidence at the university level. Moreover, the study of the actual experience of universities from developed countries in the field of international activities and assessment of the influence of internationalization progress in these universities on the state of their competitiveness is advisable in terms of finding out specific constituents of the universities' success in the field of internationalization and shaping competitive advantages. All the issues mentioned above prove the relevance of this study.

This study is aimed at estimation of the relationship between internationalization and competitive positions of higher education institutions, on the example of three European universities, and on this basis determining to what extent internationalization impacts university competitiveness.

The results of numerous theoretical studies show growing importance of internationalization for maintaining the universities competitiveness and improving the quality of educational services. For instance, the internationalization of curricula is considered to be a recognized tool for improving the quality of education. J. Salmi determines three key factors of the world class universities success, putting concentration of talent or internationalization in the first place [7]. The concentration of talent relates to the human resources of the university - its students and staff. The world-class university is capable of attracting the best scholars and students on a competitive basis. Since talents are considered to be evenly distributed around the world, the "concentration of talent" characteristic automatically indicates the high degree of foreign students and staff in these universities. Accordingly, researchers agree that the "concentration of talent" in this context is identical to the term "internationalization". J. Sandlak and Liu Nian Kai came to the conclusion that foreign students, faculty and other manifestations of internationalization became a measure of competitiveness in the educational environment [8].

The progress of internationalization and its impact on the university competitiveness are studied on the example of three European universities: University of York (UK), University of Tartu (the Republic of Estonia), Vytautas Magnus University (the Republic of Lithuania). The choice of universities for analysis is explained by the following circumstances:

1) these universities represent the EU countries that differ in levels of economic development and higher education systems;

2) the universities are highly differentiated in terms of competitiveness and internationalization progress, and are differently presented in main universities rankings (Table $1)$; 
Table 1

The universities under consideration in world universities rankings

\begin{tabular}{|l|c|c|c|}
\hline \multicolumn{1}{|c|}{ Ranking } & $\begin{array}{c}\text { University of } \\
\text { York }\end{array}$ & $\begin{array}{c}\text { University of } \\
\text { Tartu }\end{array}$ & $\begin{array}{c}\text { Vytautas } \\
\text { Magnus } \\
\text { University }\end{array}$ \\
\hline QS World University Rankings & + & + & + \\
\hline $\begin{array}{l}\text { Times Higher Education World } \\
\text { University Rankings }\end{array}$ & + & + & - \\
\hline $\begin{array}{l}\text { U.S. News Best Global } \\
\text { Universities Rankings }\end{array}$ & + & + & - \\
\hline Round University Ranking & + & + & + \\
\hline U-multirank & + & + & \\
\hline
\end{tabular}

3) the authors had the opportunity to study the peculiarities of the educational activities internationalization in these universities by undergoing training and internship within international programs. Thus, they've formed their own perception and vision of the internationalization progress in these institutions of higher education.

One of the problematic issues of this study is related to the identification of the university competitiveness indicator. The fact is that there are numerous indicators (financial, economic, personnel, managerial) that can give an idea of the university competitiveness level. Each country uses its own methodology for assessing the competitiveness of higher education institutions. Once there was an opinion that one of the most important indicators of the university competitiveness is the number of students. But this indicator is quantitative one, and it doesn't show the qualitative state and the real level of competitiveness. So the rank and the score of the university in world universities rankings have been chosen as the most generalizing and comprehensive assessments of the university competitiveness level.

The study of the methodology of world universities rankings (QS World University Rankings, Times Higher Education World University Rankings, U.S. News Best Global Universities Rankings, Round University Ranking, U-multirank) shows that most of them take into account indicators that characterize university's international activity and internationalization progress (Table 2).

Table 2

Indicators of internationalization as components of world universities rankings

\begin{tabular}{|l|l|c|}
\hline \multicolumn{1}{|c|}{ Ranking } & Indicators related to internationalization & $\begin{array}{c}\text { Weight of } \\
\text { indicator }\end{array}$ \\
\hline \multirow{4}{*}{$\begin{array}{l}\text { QS World University Rankings } \\
\text { University Rankings }\end{array}$} & International Faculty & $5 \%$ \\
\cline { 2 - 3 } & International Students & $5 \%$ \\
\hline \multirow{4}{*}{$\begin{array}{l}\text { Universities Rankings } \\
\text { Unews }\end{array}$} & International outlook, including: & $7.5 \%$ \\
\cline { 2 - 3 } & International-to-domestic-student ratio & $2.5 \%$ \\
\cline { 2 - 3 } & International-to-domestic-staff ratio & $2.5 \%$ \\
\cline { 2 - 3 } & International collaboration & $2.5 \%$ \\
\hline \multirow{4}{*}{ Round University Ranking } & Global research reputation & $12.5 \%$ \\
\cline { 2 - 3 } & International collaboration & $5 \%$ \\
\cline { 2 - 3 } & $\begin{array}{l}\text { Percentage of total publications with } \\
\text { international collaboration }\end{array}$ & $5 \%$ \\
\cline { 2 - 3 } & World teaching reputation & $8 \%$ \\
\cline { 2 - 3 } & World research reputation & $10 \%$ \\
\cline { 2 - 3 } & International Diversity, including: & $2 \%$ \\
\cline { 2 - 3 } & Share of international academic staff & $2 \%$ \\
\cline { 2 - 3 } & Share of international students & $2 \%$ \\
\cline { 2 - 3 } & Share of international co-authored papers & \\
\hline
\end{tabular}


ISSN 2518-1394 (Online), ISSN 2226-2822 (Print) ВІСНИК МАРІУПОЛЬСЬКОГО ДЕРЖАВНОГО УНРСИТЕТУ СЕРІЯ: ЕКОНОМІКА, 2020, ВИП 19

\begin{tabular}{|l|l|c|}
\hline \hline \multirow{4}{*}{-multirank } & Reputation outside region & $2 \%$ \\
\cline { 2 - 2 } & International level & $2 \%$ \\
\cline { 2 - 2 } & Foreign language bachelor programmes & A (Very good) \\
\cline { 2 - 2 } & Foreign language master programmes & B (Good) \\
\cline { 2 - 2 } & Student mobility & D (Berage) \\
\cline { 2 - 2 } & International academic staff & average) \\
\cline { 2 - 2 } & E (Weak) \\
\cline { 2 - 3 } & International joint publications & E (Weational doctorate degrees \\
\cline { 2 - 4 }
\end{tabular}

Source: compiled by the authors on the basis of $[5 ; 6 ; 9 ; 10 ; 11]$

Alongside it, one should recognize that so far the degree of university involvement in the processes of internationalization is not a critical factor for its competitiveness. This is confirmed by the weights of indicators of internationalization in the overall score of the university. Moreover, calculated coefficients of correlation between the overall score of top-50 universities in the QS World University Rankings and the relative numbers of the international faculty and international students are 0.1504 and 0.1552 respectively, which indicates not very tight relation between these indicators.

Nevertheless, the results of the comparative analysis of the overall score of the universities under consideration and the indicators of their internationalization in 2012 and 2019 show that, as a rule, an increase in internationalization indicators entails an increase in the overall score of the university and its improved position in the corresponding rankings (Table $3)$.

Table 3

University of York and University of Tartu in world universities rankings, including indicators of internationalization, 2012 and 2019

\begin{tabular}{|l|c|c|c|c|}
\hline \multirow{2}{*}{ Rankings } & \multicolumn{2}{c|}{ University of York } & \multicolumn{2}{c|}{ University of Tartu } \\
\cline { 2 - 5 } & $\mathbf{2 0 1 2}$ & $\mathbf{2 0 1 9}$ & $\mathbf{2 0 1 2}$ & $\mathbf{2 0 1 9}$ \\
\hline QS World University Rankings, rank & $\mathbf{1 1 0}$ & $\mathbf{1 3 4}$ & $\mathbf{5 0 1 - 5 5 0}$ & $\mathbf{3 2 1}$ \\
\hline - Overall Score & 63.75 & 52.4 & - & 32.8 \\
\hline - International Faculty & 84.5 & 92 & - & 22.4 \\
\hline - International Students & 81.4 & 68.2 & - & 20 \\
\hline $\begin{array}{l}\text { Times Higher Education World University } \\
\text { Rankings, } \text { rank }\end{array}$ & $\mathbf{1 2 1}$ & $\mathbf{1 1 9}$ & $\mathbf{3 5 0 - 4 0 0}$ & $\mathbf{3 0 1 - 3 5 0}$ \\
\hline - Overall Score & 50.4 & 59.3 & - & $42.4-45.1$ \\
\hline - International outlook & 72.7 & 84.9 & 42 & 51.9 \\
\hline $\begin{array}{l}\text { U.S. News Best Global Universities } \\
\text { Rankings, } \text { rank }\end{array}$ & $\mathrm{n} / \mathrm{a}$ & $\mathbf{2 2 8}$ & $\mathrm{n} / \mathrm{a}$ & $\mathbf{3 2 2}$ \\
\hline - Global Score & $\mathrm{n} / \mathrm{a}$ & 58.6 & $\mathrm{n} / \mathrm{a}$ & 54.0 \\
\hline - Global research reputation, rank & $\mathrm{n} / \mathrm{a}$ & 234 & $\mathrm{n} / \mathrm{a}$ & 358 \\
\hline - International collaboration, rank & $\mathrm{n} / \mathrm{a}$ & 778 & $\mathrm{n} / \mathrm{a}$ & 625 \\
\hline $\begin{array}{l}\text { - Percentage of total publications with } \\
\text { international collaboration, rank }\end{array}$ & $\mathrm{n} / \mathrm{a}$ & 396 & $\mathrm{n} / \mathrm{a}$ & 138 \\
\hline Round University Ranking, rank & $\mathbf{1 4 7}$ & $\mathbf{1 8 5}$ & $\mathbf{5 0 2}$ & $\mathbf{3 3 5}$ \\
\hline - Overall Score & 71.618 & 72.505 & 36.62 & 60.566 \\
\hline - International Diversity, rank & 84 & 94 & 516 & 352 \\
\hline - International Diversity, score & 79.576 & 81.148 & 28.780 & 57.374 \\
\hline
\end{tabular}

Source: compiled by the authors on the basis of $[5 ; 6 ; 9 ; 10]$

The analysis of profiles of the universities under consideration presented in U-multirank demonstrates the similar results (Table 4). 
The most obvious indicators that are usually used to estimate the state of the university internationalization are the number of international students and the number of international faculty.

\section{Table 4}

U-multirank universities' profile in terms of international orientation, 2018

\begin{tabular}{|l|c|c|c|}
\hline & $\begin{array}{c}\text { University of } \\
\text { York }\end{array}$ & $\begin{array}{c}\text { University of } \\
\text { Tartu }\end{array}$ & $\begin{array}{c}\text { Vytautas Magnus } \\
\text { University }\end{array}$ \\
\hline Student mobility & B 0.15 & B 0.14 & A 0.16 \\
\hline International academic staff & A 18.5 & B 8.56 & A 11.15 \\
\hline International joint publications & A 57.3 & A 61.3 & C 34.5 \\
\hline International doctorate degrees & n/a & D 6.84 & E 0 \\
\hline
\end{tabular}

* A (Very good), B (Good), C (Average), D (Below average), E (Weak)

Source: compiled by the authors on the basis of [11]

Analysis of data on international students and international staff compared to overall score by QS World University Rankings, where 3 universities under consideration are presented, demonstrates that these internationalization indicators really matter for the score of the university and consequently for its competitiveness (Fig. 1).

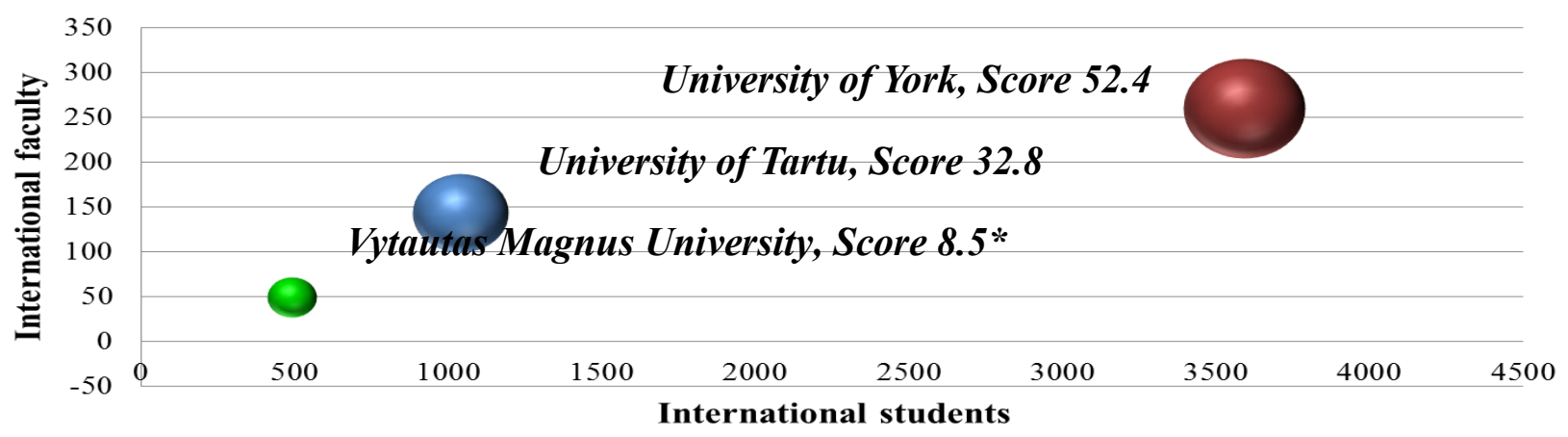

Fig. 1. International Students and Staff compared to Overall Score by QS World University Rankings, 2019

* estimated data

Thus, the progress of university internationalization apparently influences its competitiveness in the global educational space. Alongside it, the drivers and factors of the universities international success can differ significantly. To identify the specific constituents of success of the universities which have managed to make a noticeable internationalization progress and to obtain proper competitive advantages, the comparative analysis of internationalization profile of the universities has been conducted.

University of York is recognized as a leading UK university with global impact. One reason for this is the wide range of international activities in which academic staff is involved. The study of the University of York internationalization profile (Table 5) makes it possible to find out some important features that assure good internationalization progress and competitive advantages:

- the university has its International Strategy as a separate official document;

- it has a number of divisions that form a diversified university structure responsible for international activities and internationalization;

- strong emphasis is made on taking into account the special everyday habits (social, religious, living, etc.) of foreign students. 
Table 5

University of York internationalization profile

\begin{tabular}{|c|c|}
\hline $\begin{array}{l}\text { Availability of internationalization } \\
\text { strategy }\end{array}$ & Global York: International Strategy 2017-2020 \\
\hline $\begin{array}{l}\text { Availability of division responsible for } \\
\text { international activities and } \\
\text { internationalization }\end{array}$ & $\begin{array}{ll}\checkmark & \text { Directorate of External Relations: } \\
& \text { Global Engagement team (Centre for Global } \\
& \text { Programmes); } \\
\checkmark & \text { International Recruitment Team; } \\
\checkmark & \text { Interdisciplinary Global Development Centre; } \\
\checkmark & \text { International Pathway College }\end{array}$ \\
\hline Percentage of foreign students & $25 \%$ \\
\hline $\begin{array}{l}\text { Number of countries which provides } \\
\text { international students }\end{array}$ & 140 \\
\hline $\begin{array}{l}\text { Number of universities - major foreign } \\
\text { partners }\end{array}$ & Over 40 universities \\
\hline $\begin{array}{l}\text { Specific features of international activity } \\
\text { and internationalization }\end{array}$ & $\begin{array}{l}\text { Emphasis is made on adapting students to the } \\
\text { conditions of a multicultural space (intercultural } \\
\text { training is an integral part of study). } \\
\checkmark \text { The university administration tries to take into } \\
\text { account the special everyday habits (social, religious, } \\
\text { etc.) of foreign students. } \\
\checkmark \begin{array}{l}\text { Summer schools and short courses for partner } \\
\text { universities are regularly organized. }\end{array}\end{array}$ \\
\hline
\end{tabular}

Source: compiled by the authors on the basis of [13]

Developing strong teaching and research collaborations is a key factor in its international strategy and the Global Engagement team is working to create a supportive framework for departments who want to build collaborations with overseas partners.

The strengths of the University of Tartu as its internationalization profile shows (Table 6) are the following:

- a number of divisions that form a complex university structure responsible for internationalization;

- to attract more international students on the distant base emphasis is made on online learning and online courses.

\section{Table 6}

University of Tartu internationalization profile

\begin{tabular}{|c|c|}
\hline $\begin{array}{l}\text { Availability of internationalization } \\
\text { strategy }\end{array}$ & $\begin{array}{l}\text { Internationalization goals of the University are available in } \\
\text { the University's Strategic Plan for the period 2015-2020 }\end{array}$ \\
\hline $\begin{array}{l}\text { Availability of division responsible for } \\
\text { international activities and } \\
\text { internationalization }\end{array}$ & $\begin{array}{ll}\checkmark & \text { International Cooperation Unit of the Rectors Strategy } \\
\checkmark & \text { Office; } \\
\checkmark & \text { Study Abroad Centre of the Academic Affairs Office; } \\
\checkmark & \text { Lifelong Learning Centre of the Academic Affairs Office; } \\
\checkmark & \text { Grant Office; } \\
\checkmark & \text { International Marketing Unit of the Marketing and } \\
& \text { Communication Office; } \\
\checkmark & \text { Communication Unit of the Marketing and } \\
& \text { Communication Office; } \\
\checkmark & \text { Personnel Office. }\end{array}$ \\
\hline Percentage of foreign students & $6 \%$ \\
\hline $\begin{array}{l}\text { The number of countries which } \\
\text { provides international students }\end{array}$ & 90 \\
\hline
\end{tabular}




\begin{tabular}{|l|l|}
\hline \hline $\begin{array}{l}\text { Number of universities - foreign } \\
\text { partners }\end{array}$ & 72 international universities in 26 countries \\
\hline International degree programmes & $\begin{array}{l}23 \text { international degree programmes fully taught in } \\
\text { English }\end{array}$ \\
\hline $\begin{array}{l}\text { Specific features of international } \\
\text { activity and internationalization }\end{array}$ & $\checkmark$ Emphasis is made on online learning and online \\
& $\checkmark$ courses; \\
& $\checkmark$ International Summer University is a project under \\
& phich University of Tartu organizes language summer \\
& parious fields; an outstanding variety of courses on \\
& $\checkmark$ Active participation in Erasmus + programmes. \\
\hline
\end{tabular}

Source: compiled by the authors on the basis of [12]

The University of Tartu has bilateral partnership agreements with 72 partner universities from 26 countries.

Vytautas Magnus University (VMU) has a reputation as a university with a globally oriented, free-spirited, liberal mindset. Every year about 250 VMU students and 150 employees participate in the Erasmus+ exchange programme, while about 70 university students take part in VMU bilateral exchange. 25 degree study programmes are provided in English (9 BA, 16 MA) and over 500 courses are delivered in English. Vytautas Magnus University implements 2 double degree and 2 joint-degree study programmes with foreign partner universities. Emphasis is made on foreign languages which is critical for operating in a multilingual environment: University offers 30 different language courses taught by native speakers. The university has representative offices in Vilnius (Lithuania), Kharkov (Ukraine) and Washington D.C. (USA) (Table 7).

\section{Table 7}

Vytautas Magnus University internationalization profile

\begin{tabular}{|c|c|}
\hline $\begin{array}{l}\text { Availability of internationalization } \\
\text { strategy }\end{array}$ & $\begin{array}{l}\text { Internationalization goal is one of the strategic objectives } \\
\text { defined in VMU Strategy for } 2012-2020\end{array}$ \\
\hline $\begin{array}{l}\text { Availability of division responsible for } \\
\text { international activities and } \\
\text { internationalization }\end{array}$ & $\begin{array}{l}\checkmark \text { VMU International Cooperation Department: } \\
\text { - International Study Unit; } \\
\text { - International Cooperation and Marketing Unit; } \\
\text { - International Relations Group at VMU Education } \\
\text { - Academy; } \\
\text { Unit of International Cooperation Department at } \\
\text { Agriculture Academy. }\end{array}$ \\
\hline Percentage of foreign students & $7 \%$ \\
\hline $\begin{array}{l}\text { Number of universities - foreign } \\
\text { partners }\end{array}$ & over 470 universities in over 50 countries \\
\hline $\begin{array}{l}\text { Number of countries where strategic } \\
\text { partner universities function }\end{array}$ & over 60 countries \\
\hline $\begin{array}{l}\text { Specific features of international } \\
\text { activity and internationalization }\end{array}$ & $\begin{array}{l}\text { Emphasis is made on foreign languages which is } \\
\text { critical for operating in a multilingual environment: } \\
\text { University offers } 30 \text { different language courses taught } \\
\text { by native speakers; } \\
\checkmark \text { The university has representative offices in Washington } \\
\text { D.C. (USA) and Kharkov (Ukraine). }\end{array}$ \\
\hline
\end{tabular}

Source: compiled by the authors on the basis of [14]

VMU works with over 470 universities around the globe, implementing projects, student and employee exchanges, and improving study and research system. 
Summing up all mentioned above one should agree with R. Nolan and F. Hunter which point out that "every successfully internationalised university succeeds in its own particular way, while universities that fail to internationalise tend to do so in remarkably similar ways" [4]. Obviously, there is no common recipe for success in the field of internationalization and competitiveness. The practical experience of three European universities internationalization shows that international activities development is accompanied by an increase in the overall score of the university and its improved position in the universities rankings which is the evidence of the university competitiveness improvement. However, the ability of the university to develop international activities and to increase the level of competitiveness is determined by the large number of internal conditions and external factors. Identification of these conditions and factors as well as the assessment of their impact on the university competitiveness in terms of higher education internationalization can be the subject of further research in this area.

\section{References}

1. Булатова О.В. Інтернаціоналізація вищої освіти як фактор конкурентоспроможності сучасного університету / О. В. Булатова, Р. О. Толпежніков, О. С. Зайковский // Інтернаціоналізація як фактор конкурентоспроможності сучасного університету : кол. моногр. / за наук. ред. К. В. Балабанова. - Маріуполь : МДУ, 2017. C. 69-111. ; Bulatova O. V. Internatsionalizatsiia vyshchoi osvity yak faktor konkurentospromozhnosti suchasnoho universytetu / O. V. Bulatova, R. O. Tolpezhnikov, O. S. Zaikovskyi // Internatsionalizatsiia yak faktor konkurentospromozhnosti suchasnoho universytetu : kol. monohr. / za nauk. red. K. V. Balabanova. - Mariupol : MDU, 2017. - S. 69111.

2. Internationalisation of Higher Education [Electronic resource] : Study / H. de Wit, F. Hunter, L. Howard, E. Egron-Polak. - European Parliament, Brussels: EU, 2015. - Mode of access

http://www.europarl.europa.eu/RegData/etudes/STUD/2015/540370/IPOL_STU(2015)54037 $\underline{0 \_ \text {EN.pdf }}$

3. Knight J. Internationalization of Higher Education: Past and Future / J. Knight, H. de Wit // International Higher Education. - 2018. - Number 95: Fall. - P. 2-4.

4. Nolan R. Institutional strategies and programmes: Learning from experiences of change / R. Nolan, F. Hunter // The SAGE handbook of international higher education / D. Deardorff, H. de Wit, J. Heyl, T. Adams, (Eds.). - Thousand Oaks, CA: SAGE Publications, 2012. - P. 131-146.

5. QS World University Rankings [Electronic resource]. - Mode of access : https://www.topuniversities.com/university-rankings/world-university-rankings/2019

6. Round University Ranking [Electronic resource]. - Mode of access : http://roundranking.com/

7. Salmi J. The Challenge of Establishing World-Class Universities / J. Salmi. Washington DC: Directions in Development, the World Bank, 2009. - 122 p.

8. The World-Class University as Part of a New Higher Education Paradigm: From Institutional Qualities to Systemic Excellence [Electronic resource] / J. Sadlak, Liu Nian Cai (eds.). - Bucharest : UNESCO-CEPES, 2009. - 354 p. - Mode of access : http://citeseerx.ist.psu.edu/viewdoc/download?doi=10.1.1.610.3850\&rep=rep1\&type=pdf

9. Times Higher Education World University Rankings [Electronic resource]. - Mode of access : https://www.timeshighereducation.com/world-university-rankings

10. U.S. News Best Global Universities Rankings [Electronic resource]. - Mode of access : https://www.usnews.com/education/best-global-universities

11. U-multirank [Electronic resource]. - Mode of access : https://www.umultirank.org/ 
12. University of Tartu: Official Web-site [Electronic resource]. - Mode of access : https://www.ut.ee/en

13. University of York: Official Web-site [Electronic resource]. - Mode of access : https://www.york.ac.uk/

14. Vytautas Magnus University: Official Web-site [Electronic resource]. - Mode of access : https://www.vdu.lt/en/

Стаття надійшла до редакції 30.04.2020

Ю. І. Чентуков

T. В. Марена

\section{ІНТЕРНАЦІОНАЛІЗАЦІЯ ВИЩОЇ ОСВІТИ ЯК ЧИННИК ПІДВИЩЕННЯ РІВНЯ КОНКУРЕНТОСПРОМОЖНОСТІ УНІВЕРСИТЕТУ}

Статтю присвячено дослідженню взаємозв'язку між інтернаціоналізащією вищої освіти та конкурентними позиціями закладів вищої освіти на прикладі трьох європейських університетів (Університету Йорка, Тартуського Університету та Університету Вітовта Великого), а також обтрунтуванню впливу інтернаціоналізації на конкурентоспроможність університету. Зазначено, щзо місие університету $у$ світових університетських рейтингах та відповідну рейтингову оцінку можна розглядати як найбільш узагальнюючі показники рівня конкурентоспроможності університету. Виявлено, щуо методики більшості світових університетських рейтингів (QS World University Rankings, Times Higher Education World University Rankings, U.S. News Best Global Universities Rankings, Round University Ranking, U-multirank) враховують показники, які характеризують міжнародну діяльність університету та рівень його інтернаціоналізації. Однак величина ваги показників інтернаціоналізації у загальній рейтинговій оцінці університету свідчить про те, щзо поки щэо рівень участі університетів у процесах інтернаціоналізачії не $\epsilon$ критичним чинником їх конкурентоспроможності. Це підтверджують також розраховані коефіцієнти кореляиії між загальною оцінкою 50 найкращих університетів у QS World University Rankings та відносною кількістю іноземних студентів $і$ викладачів, які вказують на досить слабкий зв'язок між цими показниками.

Водночас, аналіз рейтингових позицій трьох європейських університетів та показників їх інтернаціоналізації у 2012 р. та 2019 р. продемонстрував, щзо покращення показників інтернаціоналізації, як правило, супроводжується підвищенням загальної оцінки університету та покращенням його позиџій у відповідних рейтингах. Порівняння даних університетів щзодо кількості іноземних студентів, іноземних співробітників та загальної очінки відповідно до QS World University Rankings показує, щуо чим кращими $\epsilon$ показники інтернаціоналізації, тим вищою є рейтингова оцінка університету, а отже, і рівень його конкурентоспроможності. На основі визначення основних показників та складових міжнародної діяльності університетів побудовано профрілі їх інтернаціоналізачії, порівняльний аналіз яких дозволив виявити специффічні складові успіху університетів у сфері поглиблення інтернащіоналізації та отримання відповідних конкурентних переваг.

Ключові слова: інтернаціоналізачія вищої освіти, конкурентоспроможність університету, рейтинги університетів, іноземні викладачі, іноземні здобувачі вищої освіти 